\title{
Identification of sex-linked molecular markers in Indonesian giant freshwater prawn Macrobrachium rosenbergii
}

\section{Identifikasi marka molekuler terkait kelamin pada udang galah Macrobrachium rosenbergii asal Indonesia}

\author{
Novi Megawati ${ }^{1 *}$, Alimuddin ${ }^{1}$, Ratu Siti Aliah ${ }^{2}$ \\ 'Departement of Aquaculture, Faculty of Fisheries and Marine Sciences, IPB University, Bogor 16680, \\ West Java, Indonesia \\ ${ }^{2}$ Center for Agricultural Production Technology, BPPT, Serpong 15314, Banten, Indonesia \\ "Corresponding author: novi_megawati@yahoo.com; alimuddin@apps.ipb.ac.id
}

(Received August 26, 2020; Accepted December 9, 2020)

\begin{abstract}
Male giant freshwater prawn grows faster than its female. Therefore, male mono sex culture is one of the solutions to improve aquaculture production. The all-male population of giant freshwater prawns can be produced by mating the neo-females (sex-reversed males) with the normal males. This study was aimed to identify the molecular markers related to the giant freshwater prawn sex. Specific primers were designed based on female-specific AFLP marker sequences to distinguish male and female sex on the prawns. Three locations for obtaining the Indonesian prawns in this study were Aceh, Sukabumi, and Solo. Based on the PCR analysis with MrMKn primers, 30 samples of female prawns had $100 \%$ occurred DNA bands, while no DNA bands were obtained in all-male prawns from Solo. Nevertheless, MrMKn primers still detected 10-16\% male prawns from Sukabumi and Aceh. This indicated that MrMKn primers could not yet distinguish the male prawns for all populations. Moreover, the results suggested that the three prawn samples were different based on female-specific gene sequence. The MrMKn primers have the opportunity to be used in the selection of the female ZZ (neo-female) prawns from Solo without progeny test, so that the determination of female ZZ candidates can be identified more quickly. However, the primer still needs to be redesigned to distinguish neo-female prawns from Sukabumi and Aceh.
\end{abstract}

Keyword: giant freshwater prawn, mono sex, neo-female, sex markers

\begin{abstract}
ABSTRAK
Udang galah jantan lebih cepat tumbuh dibandingkan dengan betinanya sehingga budidaya udang galah monoseks jantan menjadi salah satu solusi untuk meningkatkan produksi budidaya. Populasi monoseks jantan udang galah dapat dihasilkan dengan mengawinkan neofemales (sex-reversed males) dengan jantan normal. Sistem kromosom pada udang galah berbeda dengan ikan. Individu betina bersifat heterogametik (WZ) dan jantan homogametik (ZZ). Dalam perkembangannya, terdapat kendala dalam menentukan individu neofemale yang memiliki kromosom ZZ. Berdasarkan pendekatan sistem kromosom tersebut, maka dapat dijadikan acuan untuk membuat marka molekuler terkait kelamin udang galah. Penelitian ini bertujuan mengidentifikasi marka molekuler terkait jenis kelamin pada udang galah. Primer spesifik didesain berdasarkan sekuen female specific AFLP marker untuk membedakan kelamin jantan dan betina pada udang galah. Tiga sumber udang galah digunakan dalam penelitian ini, yaitu Aceh, Sukabumi, dan Solo. Berdasarkan hasil analisis PCR dengan primer MrKNn, dari 30 sampel pada kelompok udang galah betina diperoleh hasil 100\% pita DNA muncul, dan tidak terdapat pita DNA pada semua udang galah jantan asal Solo. Namun demikian, primer MrMKn tersebut masih mendeteksi sebesar 10-16\% pada udang galah asal Sukabumi dan Aceh. Hal ini menunjukkan bahwa primer MrMKn belum dapat membedakan udang galah jantan dari semua populasi. Selain itu, dapat dikatakan bahwa ketiga udang galah uji adalah berbeda, khususnya sekuen gen spesifik betina. Primer MrMKn berpeluang digunakan dalam proses seleksi udang galah betina ZZ (neofemale) asal Solo tanpa harus melalui uji progeni sehingga penentuan kandidat betina ZZ lebih cepat teridentifikasi. Akan tetapi, primer masih perlu didesain ulang untuk membedakan neofemale asal Sukabumi dan Aceh.
\end{abstract}

Kata kunci: marka kelamin, monoseks, neo-female, udang galah 


\section{INTRODUCTION}

Giant freshwater prawn Macrobrachium rosenbergii is one of crustacean species with high economic value. It has some excellences, its larger body size (Suwartiningsih \& Utami, 2020) and its endurance against some of environmental factor, especially against salinity (Khasani, 2013). Due to the excellences of giant freshwater prawn caused vivid giant freshwater prawn culture in some countries in Southeast Asia, South Asia, and North Australia. Nowadays, giant freshwater prawn culture is massively developed in various countries, such as in United States of America and China (Akter et al., 2014; Zafar et al., 2015; David et al., 2018). In 2009-2012, the production of giant freshwater prawn has contributed over $57.1 \%$ of the total production of freshwater prawn Macrobrachium sp. globally (New \& Nair, 2012). The annual production of giant freshwater prawn is known over 600,000 tons in 2020 (Maliwat et $a l ., 2020)$. The northwestern of India, Vietnam, Philipines, Papua New Guinea, and north of Australia are considered as main distributor in giant freshwater prawn production activities (Banu \& Christianus, 2016; Maliwat et al., 2020).

The growth of male giant freshwater prawn is faster than the female, therefore the size of consumption is easy to reach (Sui et al., 2019; Tan et al., 2020). This attracts the aquaculturist to monosex culture of male giant freshwater prawn in order to get higher production of giant freshwater prawn with shorter rearing time (Nair \& Salin, 2012). The mono sex breeding is considered more profitable, both in agriculture and the aquaculture sectors. The profits potential are offered various, i.e better growth performance and reduce the impact of territorial nature (Lezer et al., 2015). The monosex culture of male giant freshwater prawn produces better growth performance and better weight gain than the female one, thus are more profitable economically (Arisandi, 2013; Piyaviriyakul \& Darawiroj, 2014).

The development of monosex culture of male giant freshwater prawn requires a sustainable supply of male giant freshwater prawn fry. Therefore, by mating the neo-females/ZZ (sex reversed-males) with the normal male, is one of the solutions to produce male mono sex of giant freshwater prawn (Aflalo et al., 2006; Aflalo et al., 2012). The sex chromosome of female giant freshwater prawn is heterogametic (Justo et al., 1991), with the chromosome code was WZ (Malecha et al., 1992). Furthermore, some of the previous studies has confirmed that there are other species with sex chromosome of WZ/ $\mathrm{ZZ}$, i.e., crayfish and white shrimp (Guo et al., 2019; Levy et al., 2020). Levy et al. (2020) stated that the chromosome system of WZ/ $\mathrm{ZZ}$ is commonly found in macruran decapoda crustacea (crayfish and lobster). However, until now, there is no identification report about sex chromosome mating of giant freshwater prawn from karyotyping process.

Sex identification of female giant freshwater prawn/ZZ could be determined visually and confirmed by progeny testing, yet those steps need longer time and higher cost. Thus, the PCR method found potentially to accelerate the identification of neo-female giant freshwater prawn. The study about the relationship of sex and molecular marker is less reported. Moreover, the further analysis of nucleotide sequences has shown that this marker is specific female alleles (Jiang \& Qiu, 2013). Currently, there has been no verify the sensitivity of the marker that reported by Jiang and Qiu (2013) in the giant freshwater prawn in Indonesia. According to those informations, this study is done to identify sex-linked molecular of giant freshwater prawn by using specific primer, allowing to identify the sex in early development stage of giant freshwater prawn when the phenotype differentiation is yet unidentified. The aim of this study was to verify the sensitivity of MrMK primer and to obtain specific primer that may to distinguish the sex of three populations of giant freshwater prawn in Indonesia. The result of this study is expected can be used to identify the sex in early development stage of giant freshwater prawn and is expected can be applied in the next individual selection stage as the result of sex reversal, thus to minimize selection time.

\section{MATERIAL AND METHOD}

\section{Tested fish}

Tested fish that used in this study was the population of male and female giant freshwater prawn obtained from Aceh (Sungai Peurlak) and Solo (Sungai Bengawan Solo), and male and female giant freshwater prawn of SIRATU variety. Giant freshwater prawn of SIRATU variety comes from three different varieties, i.e., from Sungai Bone, Sungai Mahakam, and Sungai Citanduy with nine crossbreed combinations. The individual selection was done in Pelabuhan Ratu therefore this giant freshwater prawn is called 
SIRATU giant freshwater prawn, as mentioned in A Decree of Ministry of Marine Affairs and Fisheries Republic of Indonesia number 25/ Kepmen-KP/2015 on April 16 ${ }^{\text {th }}$, 2015. The giant freshwater prawn weighed about 50 to 60 grams/ individual.

All populations of giant freshwater prawn were directly acclimated at less than 60 mins. After that, the giant freshwater prawn was put into a rearing basket sizing of $30 \mathrm{~cm} \times 20 \mathrm{~cm} \times 10 \mathrm{~cm}$ with 1 individual/rearing basket in order to minimize the cannibalism since the giant freshwater prawn was still weak. The rearing baskets were put into a fiber tank sizing of $240 \mathrm{~cm} \times 150 \mathrm{~cm} \times 50 \mathrm{~cm}$ with a volume of $1.8 \mathrm{~m}^{3}$. The water level of each rearing tank was between $30-40 \mathrm{~cm}$ with aeration system, water inlet, and outlet pipe. Female and male giant freshwater prawn were reared in rearing tank separately. The water was siphoning off every day, to remove the sediment of waste in the bottom of the tank. The tank was cleaned up once in couple days by draining the water, brushing the tank, and cleaning the feces and feed waste, therefore the hygiene of the tank and the water quality remain maintained.

The feed was commercial feed types pellet food with high protein, squid, and tubers. The feeding frequency was four times a day. Squid and pellet feeding was given at daytime. Meanwhile, at the evening, the giant freshwater prawn fed with sweet potato. As many as 30 male and female giant freshwater prawns from three populations were collected to perform the DNA genome collection. The giant freshwater prawn that used for this study were already experienced sex differentiation. The sex was differentiated based on Aflalo et al. (2006).

\section{Genome extraction}

The genome extraction method was based on Sambrook manual book (1989). The DNA extraction was performed using pleopods pieces. A phenol chloroform method was used for DNA extraction. The extraction sample can be stored in refrigerator with temperature of $-20^{\circ} \mathrm{C}$ until it is ready to be used.

\section{The verification of MrMK primer sensitivity}

The verification of MrMK primer sensitivity that designed by Jiang and Qiu (2013) was used nine giant freshwater prawns from Sukabumi. The primer of MrMK sequences are forward 5'-GATGAGTCCTGAGTAACAA-3' (19 bp) and reverse 5'-GCACTTAACCATGCGTCAG-3'
(19 bp). As an internal control, the DNA loading was $\beta$-actin primer (forward 5'-GTGCGTGACATCAAGGAA-3' and reverse 5'- TAAGTGGTCTCGTGAATGC-3'). Amount $1 \mu \mathrm{g}$ of DNA was used as PCR sample, then it mixed with $1 \mu \mathrm{L}$ of forward and reverse primer (10 pmol/), $5 \mu \mathrm{L}$ of MyTaq Redmix (Bioline, USA), and it added with nuclease-free water until the final volume reached $10 \mu \mathrm{L}$. The PCR process was run in $95^{\circ} \mathrm{C}$ for five mins, 1 cycle; $\left(95^{\circ} \mathrm{C}\right.$ for $30 \mathrm{sec} ; 49,5^{\circ} \mathrm{C}$ for $35 \mathrm{sec} ; 72^{\circ} \mathrm{C}$ for $\left.30 \mathrm{sec}\right), 35$ cycles; $72^{\circ} \mathrm{C}$ for 2 mins, 1 cycle. Amount $3 \mu \mathrm{L}$ of DNA product of PCR amplification was used for electrophoresis using 1\% agarose gel and DNA marker. The visualization of DNA bands was performed by using GelDoc and ultra violet light.

\section{DNA purification}

The DNA fragment as the result of PCR amplification was purified from agarose gel to minimize the DNA contamination while DNA ligation. The PCR result was electrophoresis by using $1.5 \%$ of agarose gel, then the DNA was isolated from the gel by using a Geneaid ${ }^{\mathrm{TM}} \mathrm{Gel}$ kit or PCR DNA Fragments Extraction kit (Geneaid, UK). The gel was cut on the part of DNA bands along with the target length, was $700 \mathrm{bp}$ and was put into microtube. Amount $3 \mu \mathrm{L}$ as the result of DNA that isolate from the gel was electrophoresis by using $1 \%$ of agarose gel to confirm the success of DNA extraction from the gel.

\section{The DNA ligation and transformation}

The DNA fragment as the result of gel purification was connected with pGEM-T Easy cloning vector. The compositions of ligation reactor were $5 \mu \mathrm{L}$ of DNA solution, $0.5 \mu \mathrm{L}$ of pGEM-T Easy, $6.5 \mu \mathrm{L}$ of $5 x$ ligation buffer, and $1 \mu \mathrm{L}$ of T4 DNA ligase enzyme (TAKARA). The incubation was performed for two hours at room temperature, then was incubated overnight in the chiller at $4^{\circ} \mathrm{C}$. Amount $6.5 \mu \mathrm{L}$ of the result of ligation reaction was mixed into the microtube with competent cells. The DNA transformation was performed by using heat shock at $42^{\circ} \mathrm{C}$ for $60 \mathrm{sec}$. After that, the sample was incubated onice for two to three mins, then $900 \mu \mathrm{L}$ of SOC solution was put into the microtube. Afterward, the microtube with bacteria of the transformation result was incubated at $37^{\circ} \mathrm{C}$ for an hour. Then the bacteria were spread on the petri disc SOB agar media contained IPTG, X-gal, and ampicillin, and was incubated at $37^{\circ} \mathrm{C}$, overnight.

The white colony that grew on the SOB agar 
media was taken up by using a steril toothpick and was put into a test tube with SOB media contained $100 \mu \mathrm{L} / \mathrm{mL}$ of ampicillin. The plasmid bacteria colony was isolated by using an alkaline lysis solution mini preparation technique (Sambrook \& Russell, 2001).

\section{The verification of the result of plasmid isolation}

The identification of the result of plasmid isolation was performed by using PCR method to find the DNA insertion. The examination of DNA insertion was performed by using MrMK primer. The PCR process was run at $94^{\circ} \mathrm{C}$ for five mins in only one cycle; $\left(94^{\circ} \mathrm{C}\right.$ for $30 \mathrm{sec} ; 51.5^{\circ} \mathrm{C}$ for 30 sec; $72^{\circ} \mathrm{C}$ for $30 \mathrm{sec}$ ) in 35 cycles; $72^{\circ} \mathrm{C}$ for two mins in one cycle; and $4{ }^{\circ} \mathrm{C}$ (unlimited). The result of positive insert PCR was clearly marked by the appear of $700 \mathrm{bp}$ of DNA bands.

\section{Sequencing and MrMK specific primer design}

The plasmid that contained DNA fragment of PCR amplification product with MrMK primer, then was sent into Firstbase Sequencing, Singapore. The MrMK primer still not worked successfully to determine all the population of giant freshwater prawn, therefore the sequencing and new primer design are still needed. The sequencing result should be aligned to find out the different area to be used for specific primer. The sequences from male and female giant freshwater prawn were aligned with BIOEDIT program ver. 7.2. Furthermore, from the alignment result, the sequence was selected (only a pair of forward and reverse primer as specific primer) for all three populations of giant freshwater prawn. The PCR optimization was done by modifying the annealing temperature, allowing the specific PCR product for female giant freshwater prawn.

\section{Data analysis}

The analysis data of isolation result and characterization of sex marker in the giant freshwater prawn was performed descriptively. The sequencing data obtained from this study, then compared with the identical level of the genome of giant freshwater prawn which has been available in the Gene Bank by using basic local alignment search tool (BLAST) software in NCBI (http://blast.ncbi.nlm.nih.gov/Blast. cgi). The trace and the alignment of sequencing result and the making of new primer design used BioEdit program, MEGA 6 (Tamura et al., 2013). The primer that was specific and accurate could determine the giant freshwater prawn in all populations.

\section{RESULT AND DISCUSSION}

\section{Result}

The verification of MrMK primer sensitivity

First, the verification of MrMK sensitivity primer was performed. The PCR result used forward dan reverse of MrMK primer showed that the product is clearly seen with DNA length bands was $700 \mathrm{bp}$ and the $\beta$-actin was around $250 \mathrm{bp}$ (Figure 1). Afterward, that primer was tested with all the samples of giant freshwater prawn from Aceh, Sukabumi, and Solo. The recapitulation of PCR testing result showed in the Table 1 below. All the samples of female giant freshwater prawn from three different locations have been detected with DNA length bands was $700 \mathrm{bp}$, meanwhile there still was $16 \%$ of male giant freshwater prawn from Solo and 30\% of each giant freshwater prawn from Aceh and Sukabumi. By this, the further step, new primer is designed.

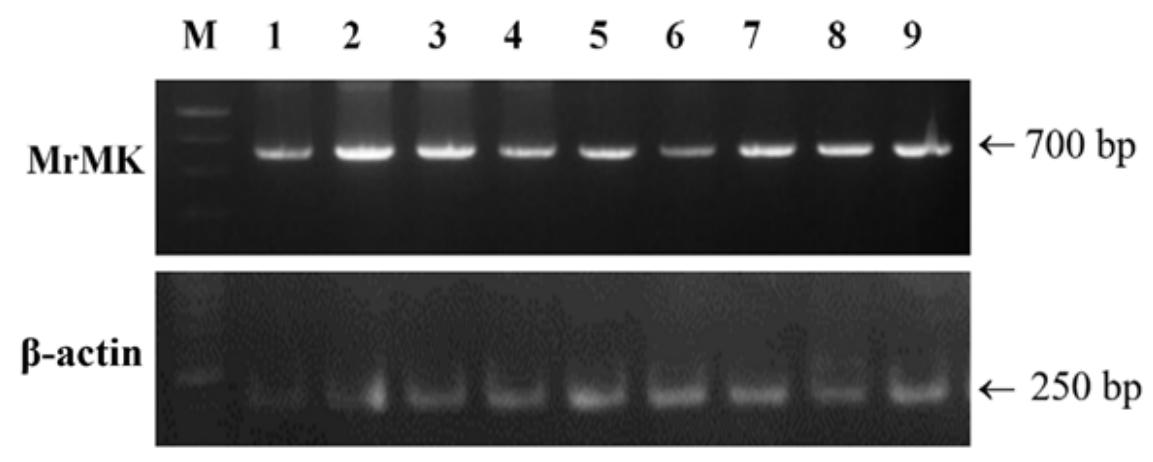

Figure 4. Nitrogen output distribution in biofloc-based C. gariepinus culture at different densities (500, 750, and $1000 \mathrm{fish} / \mathrm{m}^{3}$ ) and a control after 8 weeks of culture. 
Sequencing, new primer design, and sensitivity test

The PCR product of female giant freshwater prawn measuring 700 bp of DNA bands length was cloned to cloning vector. Then the plasmid used for sequencing. This study used three different colonies for the sequencing. The sequencing result of PCR product and its alignment showed in Figure 2. The sequencing result showed similar in all plasmid samples from bacteria colonies. From this alignment result, the sequence of male and female giant freshwater prawn obtained different area used to design a specific primer (it marked with a box and an arrow).

One set of specific primer candidate (MrMKn) used as a molecular marker as sex distinction in designated male and female giant freshwater prawn (Figure 2), i.e., forward MrMKn5'CAGTATTTCGGAWTGGTATTGCTCGGG-3' and reverse MrMKn 5'-CCGATAACTCTGCG-
AATGAGC-3' with 390 bp of DNA bands target. The MrMKn primer was tested on three different populations of male and female giant freshwater prawn. The result of this study showed that MrMKn primer was completely specific in female giant freshwater prawn with DNA band showed 390 bp (Figure 3).

According to PCR analysis results, all the population of female giant freshwater prawn from Aceh, Sukabumi (SIRATU), and Solo showed the DNA bands (Table 2). The DNA band expected did not appear in all populations of male giant freshwater prawn, yet this DNA band was unfortunately appeared in the population of male giant freshwater prawn from Aceh and Sukabumi, which each of them were $5(16 \%)$ and $3(10 \%)$. This showed that the sensitivity of MrMKn to determine the male and female giant freshwater prawn from Solo, SIRATU, and Aceh were 100\%, $90 \%$, and $84 \%$.

\begin{tabular}{|c|c|c|}
\hline Male & TTTCGGAWTGGTATTGCTCGGGATTGTTGGCCGGTACTCTGTGGGGAACCCTGAGTCCAT & 917 \\
\hline Female & 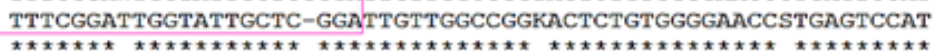 & 743 \\
\hline Male & TGATGGTCATCGAACGGGCGCCTGTCAGCCATGCGATCAACGAGTCACTACAATGGGCGG & 977 \\
\hline Female & 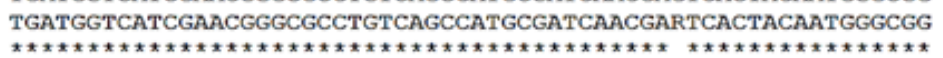 & 803 \\
\hline Male & CAGGTGCCATTACTACGCTGATAGGTCTCTCGGTCATGAAGCTTGGAGTCATGGCCATGT & 1037 \\
\hline Female & 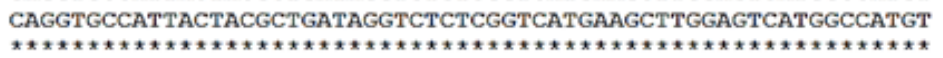 & 863 \\
\hline Male & TTCTCGCGCCGATTGCTGCCGGCCTCGTGTCCATGCTGCACGGATTCCACTATGCGGCCC & 1097 \\
\hline Female & 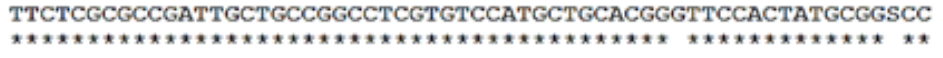 & 923 \\
\hline Male & ATCGGGTCTCCCTGCGGCCTAGTCTCCATTGGGGTAAGCAGATCGCGCAGAGTGGCATGC & 1157 \\
\hline Female & 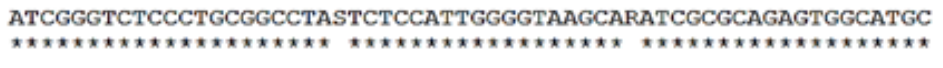 & 983 \\
\hline Male & CGGCGATCCCGTTCAGCCTGATGGATGTGGTGGCCAACAGCATGGACCGCTTTGTCATTC & 1217 \\
\hline Female & 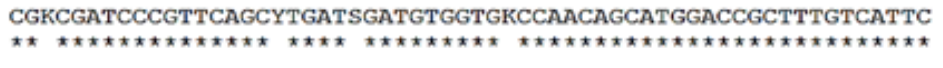 & 1043 \\
\hline Male & AGCGCTGGCTGGACCTCTCCACACTGGGCATTTATGCTCATTCGCAGAGTTATCGGGGAA & 1277 \\
\hline Female & 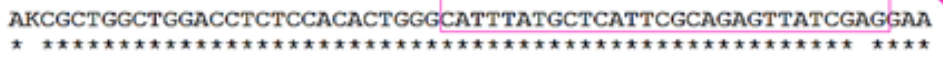 & 1103 \\
\hline
\end{tabular}

Figure 2. The alignment of DNA sequences of male and female giant freshwater prawn as the result of sequencing with MrMK primer.

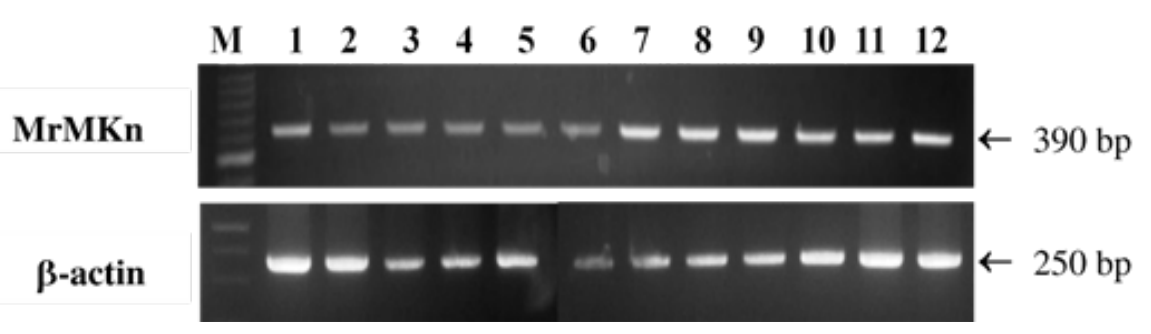

Figure 3. The PCR amplification with MrMKn primer in female giant freshwater prawn with DNA bands showed $390 \mathrm{bp}$ (up), and the $\beta$-actin was $250 \mathrm{bp}$ (bottom). The arrow at the right side showed the PCR product target. $\mathrm{M}=$ DNA marker; $1-12=$ the number of genome sample of giant freshwater prawn. 


\section{Discussion}

Jiang and Qiu (2013) have already succeeded in obtaining specific primer of sex markers in the giant freshwater prawn in China. Furthermore, the MrMK primer has already verified its sensitivity in three different populations of giant freshwater prawn in Indonesia, yet the MrMK primer still could not determine specifically between male and female individuals, and not all the samples of giant freshwater prawn had a PCR product (Table 1). Therefore, the PCR product from male and female giant freshwater prawn were purified, then were sequenced to obtain the area that has selected as new specific primer target. The PCR product purification was intended to eliminate impurities in samples because it can disrupt the processes, i.e., DNA ligation, cloning, labelling sequencing, PCR, and RTPCR (Santo et al., 2017; Dwiyitno et al., 2018).

Table 1. The sex identification of giant freshwater prawn used MrMK primer in male and female giant freshwater prawn from Aceh, Sukabumi (SIRATU), and Solo.

\begin{tabular}{cccc}
\hline Sample & Sex & $\begin{array}{c}\text { Positive } \\
\text { PCR product } \\
\text { (individual) }\end{array}$ & $\begin{array}{c}\text { Percentage } \\
(\%)\end{array}$ \\
\hline Aceh & Female & 30 & 100 \\
SIRATU & Female & 30 & 100 \\
Solo & Female & 30 & 100 \\
Aceh & Male & 9 & 30 \\
SIRATU & Male & 9 & 30 \\
Solo & Male & 5 & 16 \\
\hline
\end{tabular}

According to the alignment data of sequencing result, one set primer was selected to be a sex marker of giant freshwater prawn from Indonesia. That area was selected because the 3 end was played important role when annealing and primer extension when PCR started (Yustinadewi et al., 2018). Afterward, the nucleotide bases $G$ and $\mathrm{C}$ that had three hydrogen bonds was remained stable than nucleotide bases A and $\mathrm{T}$ that only had two hydrogen bonds (Poater et al., 2014; Nur'aini et al., 2019). The PCR process involved various steps, i.e., denaturation, primer annealing, and primer extension (Porta \& Enners, 2012; Fitriatin \& Manan, 2015). The optimal annealing temperature annealing should be noticed. The temperature optimization for annealing process was made for the primer to attach better, to multiply the PCR product, and to increase DNA specificity (Kurniawati \& Hartati, 2018). The MrMKn primer in this study has DNA bands length of $390 \mathrm{bp}$. The optimalization result showed that the best annealing temperature was $43^{\circ} \mathrm{C}$, meanwhile Walker and Rapley (2002) stated that the recommendation of annealing temperature is between $40-60^{\circ} \mathrm{C}$. The error of primer attachment can occur when the annealing temperature is too low. Yet, some of primers also can not attach well when the temperature is significantly increased (Naqib et al., 2019).

Based on PCR analysis, within 30 samples of giant freshwater prawn from Solo, the DNA bands were showed $100 \%$, and the DNA bands were not occuring in all male giant freshwater prawn (Table 2). However, the MrMKn primer sensitivity in the giant freshwater prawn from Aceh was $84 \%$ and from SIRATU was $90 \%$ (Table 2). It showed that MrMKn primer still could not determine male giant freshwater prawn

Table 2. The result of the performance of MrMKn primer in male and female giant freshwater prawn from Aceh, Sukabumi (SIRATU), and Solo.

\begin{tabular}{cccc}
\hline Sample & Sex & $\begin{array}{c}\text { Positive } \\
\text { PCR product } \\
\text { (individual) }\end{array}$ & $\begin{array}{c}\text { Percentage } \\
(\%)\end{array}$ \\
\hline Aceh & Female & 30 & 100 \\
SIRATU & Female & 30 & 100 \\
Solo & Female & 30 & 100 \\
Aceh & Male & 5 & 16 \\
SIRATU & Male & 3 & 10 \\
Solo & Male & 0 & 0 \\
\hline
\end{tabular}

in all populations. In the early stage, the primer was designed by the result from BLAST and was spesific. Nevertheless, the lack of the information about the genome sequence of giant freshwater prawn in Indonesia could complicate to collect specific primer of all populations. Moreover, it concluded that the giant freshwater prawn used in this study was totally different, especially the genome sequence of sex. The MrMKn primer can be used in the selection process of $\mathrm{ZZ}$ female giant freshwater prawn from Solo without progeny test, therefore the determination of $\mathrm{ZZ}$ female candidate can be faster. Yet, the primer is still needs to redesign to determine the neofemale from Sukabumi and Aceh. The further study can be performed by isolating the whole sequences to obtain other candidate from different areas to determine some population of giant freshwater 
prawn in Indonesia. Some studies showed that there is a potency that several sex genes can be used as markers. Yu et al. (2014) explained that the result of qPCR analysis of Dmrt genes in the giant freshwater prawn showed a different gene's expression pattern in the development of sexual dimorphism and the embryo, i.e., MroDmrt11E andMroDmrt99bgene. Furthermore, the content of $\mathrm{N}$-acetyltransferase and melatonin in optic lobe of male giant freshwater prawn was not significantly different, yet in female giant freshwater prawn was otherwise (Withyachumnarnkul et al., 1999).

\section{CONCLUSION}

This study proved that the MrMKn primer could determine $\mathrm{ZZ}$ male and $\mathrm{ZZ}$ female of giant freshwater prawn from Solo specifics, yet it could not determine the giant freshwater prawn from Aceh and Sukabumi (SIRATU). The further study should be performed to obtain specific primer that can determine all populations of giant freshwater prawn in Indonesia.

\section{REFERENCES}

Aflalo ED, Hoang TTT, Nguyen VH, Lam Q, Nguyen DM, Trinh QS, Raviv S, Sagi A. 2006. A novel two-step procedure for mass production of all-male populations of the giant freshwater prawn Macrobrachium rosenbergii. Aquaculture 256: 468-478.

Aflalo ED, Raju DVSN, Bommi NA, Verghese JT, Samraj TYC, Hulata G, Ovadia O, Sagi A. 2012. Toward a sustainable production of genetically improved all-male prawn Macrobrachium rosenbergii: Evaluation of production traits and obtaining neo-females in three Indian strains. Aquaculture 338-341: 197-207.

Akter S, Hossain MMM, Bappa SB, Dey BK, Uz Zaman MF. 2014. Farming of giant freshwater prawn Macrobrachium rosenbergii in Bagerhat, Bangladesh. Journal of Fisheries 2: 187-194.

Arisandi A. 2013. Toksisitas hormon $17 \alpha$-metiltestosteron terhadap aspek reproduksi udang galah. Jurnal Rekayasa 6: 37-47.

Banu R, Christianus A. 2016. Freshwater prawn Macrobrachium rosenbergii farming: A review on its current status and prospective in Malaysia. Journal of Aquaculture 7: 1-5.
David FS, Fonseca T, Bueno GW, Valenti WC. 2018. Economic feasibility of intensification of Macrobrachium rosenbergii hatchery. Aquaculture Research 49: 3769-3776.

Dwiyitno, Hoffman S, Parmentier K, Keer CV. 2018. Method comparison of DNA isolation and quantification for fish and seafood authenticity determination. Squalen Bulletin of Marine and Fisheries Postharvest and Biotechnology 13: 115-124.

Fitriatin E, Manan A. 2015. Viral nervous necrosis (VNN) examination at fish by polymerase chain reaction (PCR) method. Jurnal Ilmiah Perikanan dan Kelautan 7: 149-152.

Guo L, Xu YH, Zhang N, Zhou FL, Huang JH, Liu BS, Jiang SG, Zhang DC. 2019. A high-density genetic linkage map and QTL mapping for sex in black tiger shrimp Penaeus monodon. Frontiers in Genetics 10: 326.

Jiang XH, Qiu GF. 2013. Female only sex linked amplified fragment length polymorphism markers support ZW/ZZ sex determination in the giant freshwater prawn Macrobrachium rosenbergii. Animal Genetic 44: 782-785.

Justo CC, Murofushi M, Aida K, Hanyu I. 1991. Karyological studies on the freshwater prawn Macrobrachium rosenbergii. Aquaculture 97: 327-334.

Khasani I. 2013. Penyakit ekor putih (white muscle disease) pada udang galah Macrobrachium rosenbergii de Man. Media Akuakultur 8: 31-37.

Kurniawati S, Hartati S. 2018. Optimization of the annealing temperature with degenerate primer for amplification of arginine decarboxylase (ADC) fragment gene from genomic DNA of Maluku Tenggara local cassava. Jurnal Ilmu Dasar 19: 135-142.

Levy T, Ventura T, De Leo G, Grinshpan N, Abu Abayed FA, Manor R, Savaya A, Sklarz MY, Chalifa-Caspi V, Mishmar D, Sagi A. 2020. Two homogametic genotypes - one crayfish: on the consequences of intersexuality. Science 23: 101652.

Lezer Y, Aflalo ED, Manor R, Sharabi O, Abilevich LK, Sagi A. 2015. On the safety of RNAi usage in aquaculture: The case of all-male prawn stocks generated through manipulation of the insulin-like androgenic gland hormone. Aquaculture 435: 153-166.

Malecha SR, Nevin PA, Ha P, Barck LE, Lamadrid-Rose Y, Masuno S, Hedgecock D. 1992. Sex-ratios and sex-determination 
in progeny from crosses of surgically sexreversed freshwater prawns, Macrobrachium rosenbergii. Aquaculture 105: 201-218.

Maliwat GFC, Velasquez SF, Buluran SMD, Tayamen MM, Ragaza JA. 2020. Growth and immune response of pond-reared giant freshwater prawn Macrobrachium rosenbergii post larvae fed diets containing Chlorella vulgaris. Aquaculture Research.

Nair CM, Salin KR. 2012. Current status and prospects of farming the giant river prawn Macrobrachium rosenbergii (De Man) and the monsoon river prawn Macrobrachium malcolmsonii (H.M. Edwards) in India. Aquaculture Research 43: 999-1014.

Naqib A, Jeon T, Kunstman K, Wang W, Shen Y, Sweeney D, Hyde M, Green SJ. 2019. PCR effects of melting temperature adjustment of individual primers in degenerate primer pools. PeerJ 6570.

New MB, Nair CM. 2012. Global scale of freshwater prawn farming. Aquaculture Research 43: 960-969.

Nur'aini S, Mukaromah AS, Muhlisoh S. 2019. Pengenalan deoxyribonucleic acid (DNA) dengan marker-based augmented reality. Walisongo Journal of Information Technology 1: 91-100.

Piyaviriyakul P, Darawiroj D. 2014. Timing for male reproductive tract gene expression and gonopore complex development of giant freshwater prawn Macrobrachium rosenbergii. The Thai Journal of Veterinary Medicine 44: 523-531.

Poater J, Swart M, Bickelhaupta FM, Guerra CF. 2014. B-DNA structure and stability: the role of hydrogen bonding, $\pi-\pi$ stacking interactions, twist-angle, and solvation. Organic \& Biomolecular Chemistry 12: 4691.

Porta AR, Enners E. 2012. Determining annealing temperatures for polymerase chain reaction. The American Biology Teacher 74: 256-260.

Sambrook J. 1989. Molecular Cloning: a Laboratory Manual. Cold Spring Harbor Laboratory, New York.

Sambrook JF dan Russel DW. (Ed). 2001. Molecular Cloning: A Laboratory Manual. New York: Cold Spring Harbor Laboratory.

Santosa F, Gómez-Manzoc S, Sierra-Palacios E, González-Valdeze A, Castillo-Villanuevac A, Reyes-Vivasc H, Marcial-Quino J. 2017. Purification, concentration and recovery of small fragments of DNA from Giardia lamblia and their use for other molecular techniques. Methods 4: 289-296.

Sui J, Luan S, Yang G, Xia Z, Luo K, Tang Q, Lu X, Meng X, Kong J. 2019. Genetic parameters and selection response for the harvest body weight of the giant freshwater prawn Macrobrachium rosenbergii in a breeding program in China. PLoS One 14: 1-17.

Suwartiningsih N, Utami LB. 2020. Morphological variation of giant freshwater prawn Macrobrachium rosenbergii de Man, 1879 broodstock of Siratu, GIMacro, Mahakam, and Bengawan Solo populations. Depik Jurnal Ilmu-Ilmu Perairan, Pesisir dan Perikanan 9: 220-226.

Tamura K, Stecher G, Peterson D, Filipski A, Kumar S. 2013. MEGA: Molecular evolutionary genetics analysis version 6.0. Molecular Biology Evolution 30: 2725-2729.

Tan T, Jiang H, Jiang D, Wang W. 2020. Sex reversal and the androgenic gland (AG) in Macrobrachium rosenbergii: A review. Aquaculture and Fisheries 5: 283-288.

Walker JM and Rapley R. 2002. Molecular biology and biotechnology fourth edition. The Royal society of Chemistry. 555p.

Withyachumnarnkul B, Ajpru S, Rachawong S, Pongsa-Asawapaiboon A, Sumridthong A. 1999. Sexual dimorphism in $\mathrm{N}$-acethyltransferase and melatonin levels in the giant freshwater prawn Macrobrachium rosenbergii de Man. Journal of Pineal Research 26: 174-177.

Yu YQ, Ma WM, Zeng QG, Qian YQ, Yang JS, Yang WJ. 2014. Molecular cloning and sexually dimorphic expression of two Dmrt genes in the giant freshwater prawn, Macrobrachium rosenbergii. Agricultural Research 3: 181-191.

Yustinadewi PD, Yustiantara PS, Narayani I. 2018. MDR-1 gene 1199 variant primer design techniques in pediatric patient buffy coat samples with LLA. Journal of Biological Science 5: 105-111.

Zafar M, Soomro MH, Daudpota AM, Memon AJ, Ishaqi AM. 2015. Effect of different salinities on survival of freshwater prawn Macrobrachium rosenbergii larvae at seed production unit Hawksbay Karachi-Pakistan. International Journal of Interdisciplinary and Multidisciplinary Studies 2: 165-169. 